\title{
Changes in the Horizontal Polyacrylamide Gradient Gel Electrophoretic Patterns of Chicken Egg Yolk Protein After Heating
}

\author{
Noriko Ogawa and Hisako TANABE \\ Department of Nutrition and Food Science, Faculty of Home Science, \\ Gifu Women's University, 80 Taromaru, Gifu 501-25, Japan
}

\begin{abstract}
Heat denaturation of fresh and stored chicken yolk proteins was studied by horizontal polyacrylamide gradient gel electrophoresis. The egg yolk samples were separated from eggs and stored at $28^{\circ} \mathrm{C}$ for six weeks, and heated at $80^{\circ} \mathrm{C}$ for 0-20 minutes. Electrophoretograms of egg yolk proteins were divided into six zones: (1) the prealbumin zone having bands 1 through 8 . (2) the albumin zone having band 9. (3) the postalbumin zone having bands 10 and 11 . (4) the pretransferrin zone having bands 12 and 13 . (5) the transferrin zone having bands 14 and 15. (6) the posttransferrin zone having bands 16 and 17 . The high heat stable proteins which remained stable until 20 minutes of heating were bands $1,3,6$ and 7 in the prealbumin zone, and band 10 in the postalbumin zone. The medium heat stable proteins which were present until 5 minutes after heat, and barely visible or absent after 20 minutes of heat, were band 2 in the prealbumin zone, band 11 in the postalbumin zone, and band 13 in the pretransferrin zone. The most heat sensitive yolk proteins were in band 4 in the prealbumin zone, band 9 in the albumin zone, band 12 in the pretransferrin zone, bands 14 and 15 of the transferrin zone, and bands 16 and 17 in the posttransferrin zone.

In the stored egg yolks, band 9 in the albumin zone was still present after heating for 20 minutes at $80^{\circ} \mathrm{C}$, and transferrin band 14 disappeared after heat for 10 seconds.
\end{abstract}

(Jpn. Poult. Sci., $26: 333-339,1989$ )

Key words: Chicken egg, egg yolk, storage of chicken egg, heat-stability, electrophoresis

\section{Introduction}

The effect of heating on the structural and functional properties of chicken egg white proteins is different between fresh and stored eggs. Changes in texture properties of heated egg yolk after storage have been reported by OGAwA et al. ${ }^{1}$, but changes in the electrophoretic patterns of heated egg yolk have not been reported. TANABE et $a l .^{2)}$ reported that horizontal polyacrylamide gel electrophoresis with its superior high resolution was an effective technique for assessing the influence of heat and storage treatments on chicken egg white proteins, and found a new polymorphic ovoglobulin G4 which was not stable both in fresh and stored egg white after being heated at $70^{\circ} \mathrm{C}$ for 5 minutes. TANABE et al. ${ }^{3,4)}$ examined the electrophoretic patterns of yolk and blood plasma proteins, and found new polymorphic proteins of prealbumin-3 in egg yolk, and of prealbumin-2 in yolk and blood plasma of laying pullets. 
The present study was to describe the degree of heat denaturation of the fresh chicken yolk proteins by using the horizontal polyacrylamide gel electrophoresis, and to describe the degree of heat denaturation of the stored yolk proteins.

\section{Material and Methods}

\section{Egg Yolk Samples}

Fresh eggs were obtained from White Leghorn pullets kept at the Gifu Prefectural Poultry Breeding Station. The egg yolk was separated from the eggs and stored at 28 ${ }^{\circ} \mathrm{C}$ for six weeks. Fresh and stored yolks were diluted with the same volume of $0.9 \%$ $\mathrm{NaCl}$ solution and mixed thoroughly. The diluted egg yolk samples were soaked in $6 \mathrm{~mm} \times 2 \mathrm{~mm}$ pieces of filter paper (Toyo No. 514). One filter paper contained about $16 \mathrm{mg}$ samples, and sealed in a polyethylene film, then heated in a preheated water bath at $80^{\circ} \mathrm{C}$ for $0,1,2,3,5,10$ and 20 seconds and 1 to 20 minutes at 1 minute intervals. After heat treatment, each piece of filter paper was cooled and was applied on the gel to analyze the electrophoretic patterns.

\section{Blood Samples}

Blood was collected from laying pullet by heparinized syringe. Blood plasma was obtained by centrifugation at 3,000 rpm for 10 minutes.

\section{Electrophoresis}

Horizontal polyacrylamide gradient gel electrophoresis was performed by using a slight modification of GAHNE et al. ${ }^{5)}$. Running buffer was $0.13 \mathrm{M}$ Tris-borate buffer ( $\mathrm{pH} 9.2$ ), and gel buffer was $0.1875 \mathrm{M}$ Tris-borate $(\mathrm{pH} 9.0)$. Step gradient gels (24 cm width, $20 \mathrm{~cm}$ length, $1-1.2 \mathrm{~cm}$ thickness) were $10 \%(16 \mathrm{~cm}), 4 \%(3 \mathrm{~cm}), 8 \%$ $(1 \mathrm{~cm})$ polyacrylamide concentration, respectively (Fig. 1). Electrophoresis was carried out at a constant current of $1.25 \mathrm{~mA} / \mathrm{cm}$ at $4^{\circ} \mathrm{C}$ for $2.5 \mathrm{hr}$. The filter paper pieces, containing the samples, were after 20 minutes. After electrophoresis, the $10 \%$ gel of polyacrylamide concentration was stained overnight with Commasie brilliant blue $-\mathrm{R}$ in $3.5 \%$ perchloric acid. The back ground was destained in $5 \%$ acetic acid for about 30 minutes $^{4)}$.

In this experiment, relative comparison of electrophoretic patterns of fresh chicken egg yolk proteins and of egg yolk proteins after being heated were made.

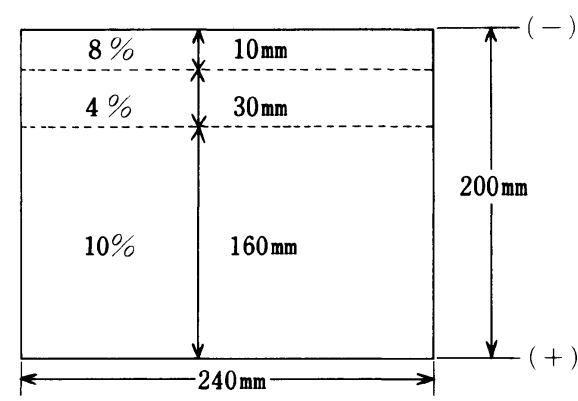

Fig. 1. Schematic presentation of the polyacrylamide gel used in this experiment. $16 \mathrm{mg}$ of egg yolk sample was soaked in some pieces of filter paper and was applied on the middle of the $4 \%$ gel. 


\section{Result}

The horizontal polyacrylamide gradient gel electrophoretograms of fresh chicken egg yolk and blood plasma proteins are shown in Figure 2. The densest band in blood plasma was designated albumin. In electrophoretic patterns of chicken yolk proteins, band 9 was the densest and moved to the same position as the albumin band in blood plasma. The second densest bands in the yolk were bands 10 and 11 in the postalbumin zone. In the prealbumin zone, bands 1 through 8 were separated. Bands 1 and 7 were present in the yolk and were not present in blood plasma. Bands 2 and 3 through 6 were present either in blood plasma or yolk.

Bands 14 and 15 in the yolk was identified with the transferrin zone by radioactive labeling with ${ }^{59} \mathrm{Fe}^{6}$. The mobility of the yolk transferrin bands was the same as those of the plasma transferrins. In the pretransferrin zone of yolk proteins, two different bands, 12 and 13, were observed. In the posttransferrin zone, bands 16 and 17 were observed. Changes in the electrophoretic patterns of fresh chicken egg yolk proteins after being heated for 20 minutes at $80^{\circ} \mathrm{C}$ are shown in Figure 3 . In the prealbumin zone, bands 1, 6 and 7 did not appear to decrease in intensity after being heated for 20 minutes. Bands 2 and 3 were present until 5 minutes after heat, then continue to

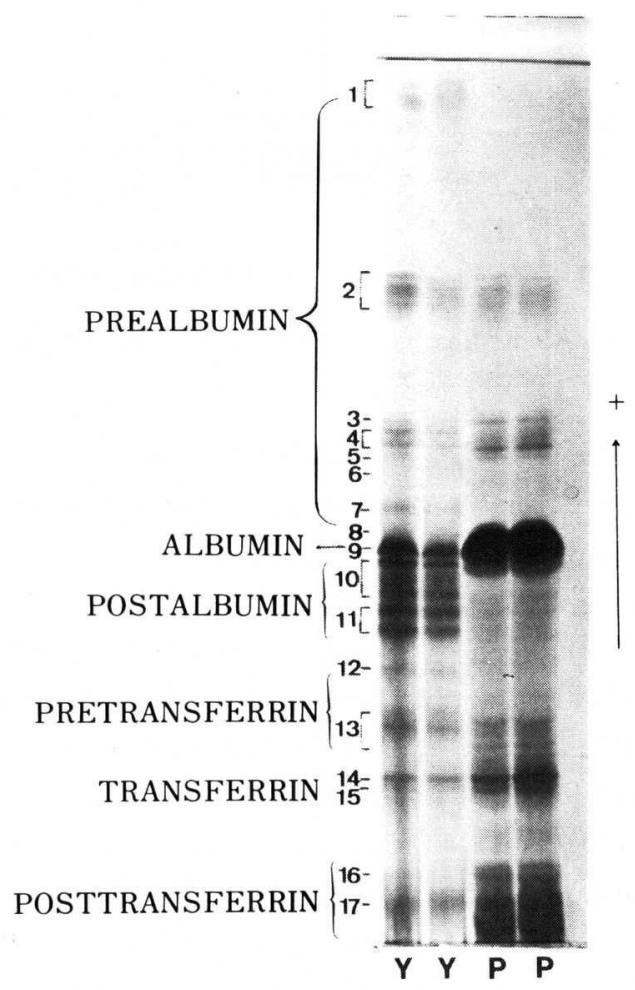

Fig. 2. Horizontal polyacrylamide gradient gel electrograms of chicken yolks and blood plasma of laying chicken egg yolk. $\mathrm{Y}$ : egg yolk, P : blood plasma of laying chicken 


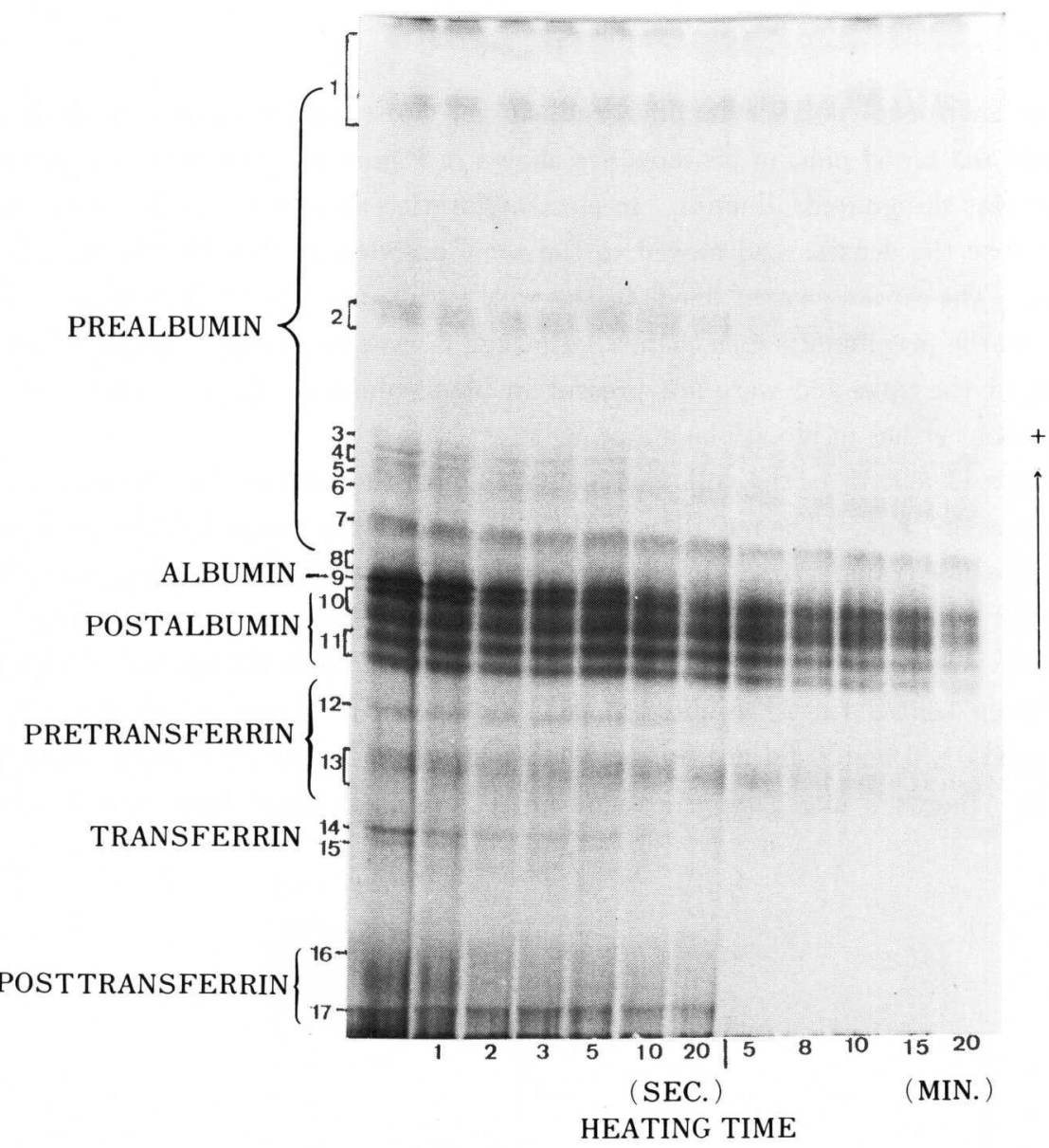

Fig. 3. Changes in the electrophoretic patterns of chicken egg yolk proteins after being heated for $20 \mathrm{~min}$, at $80^{\circ} \mathrm{C}$.

diminish, and disappeared after 20 minutes of heating. Band 4 was absent after 20 seconds of heat. Band 8 weakened after 10 seconds of heating and could not be detected after 20 seconds of heat.

In the postalbumin zone, band 10 was present with moderated intensities until 20 minutes after heat. The intensity of band 11 was almost comparable to the intensity of band 10 for the unheated sample, and continued to diminish during the heating treament for 20 minutes. In the pretransferrin zone, band 12 was absent after 20 seconds of heat. Band 13 did not appear to decrease in intensity until 5 minutes after heat, then continued to diminish and was barely visible after 20 minutes of heat. In the transferrin zone, band 14 continued to diminish and almost disappeared until 20 seconds after heat, and band 15 weakened and was barely visible after 2 seconds of heat. In the posttransferrin zone, band 16 was almost diminished in intensity after 20 seconds of heat. Band 16 was absent after 1 minute of heat.

The effect of heat on the electrophoretic patterns of chicken egg yolk stored for 6 weeks at $28^{\circ} \mathrm{C}$ is shown in Figure 4 . In the stored egg yolk, the dye intensities of band 


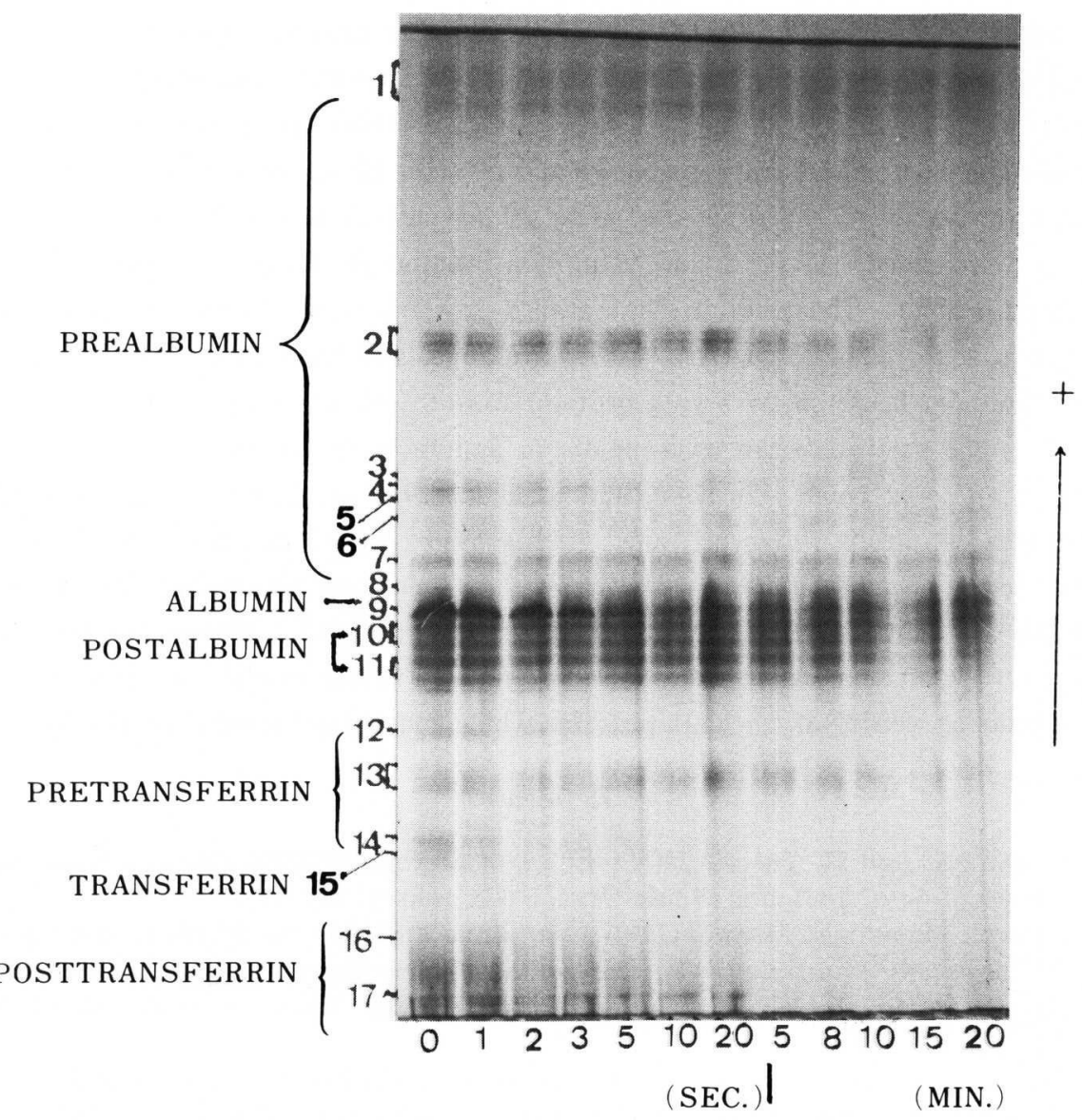

Fig. 4. Changes in the electrophoretic patterns of chicken egg yolk proteins stored for 6 weeks at $28^{\circ} \mathrm{C}$ after being heated for $20 \mathrm{~min}$. at $80^{\circ} \mathrm{C}$.

9 in the albumin zone was reduced but still present after being heated for 20 minutes at $80^{\circ} \mathrm{C}$. The transferrin band 14 was reduced in intensity and disappeared after being heated for 10 seconds at $80^{\circ} \mathrm{C}$. The other protein bands in electrophoretic patterns of stored egg yolk, except the albumin and the transferrin, did not change in intensity to any appreciable extent due to the treatment.

\section{Discussion}

Previous studies ${ }^{7,8,9)}$ on the effect of heating of chicken yolk proteins by the polyacrylamide disc gel electrophoresis showed the presence of five kinds of proteins including $\alpha$-livetins, $\beta$-livetins, $\gamma$-livetins, lipovitellin and prealbumin. GHANE et al. ${ }^{6)}$ reported the horizontal polyacrylamide gradient gel electrophoresis showed superior resolution of cattle plasma proteins. This method has been shown to be useful for detecting and for simultaneously phenotyping different proteins in the egg yolk by TANABE et $a l^{3,4)}$. The resolution of the effect of heating on yolk proteins by this method was much better than described by earlier methods. In the chicken egg yolk, 
17 electrophoretic proteins were clearly separated. Judging from the degree of the reduction of the dye intensities of protein bands after heating, the yolk proteins were divided as follows: (1) the high heat stable proteins which remained stable until 20 minutes after heat, (2) the medium heat stable proteins which were present until 5 minutes after heat, and barely visible or absent after 20 minutes of heat, (3) the heat sensitive proteins which disappeared after 20 seconds of heat. The high heat stable proteins were bands $1,3,6$ and 7 in the prealbumin zone, and band 10 in the postalbumin zone. The medium heat stable proteins were shown on band 2 in the prealbumin zone, band 11 in the postalbumin zone, and band 13 in the pretransferrin zone. The most heat sensitive yolk proteins were found in band 9 in the albumin zone, band 12 in the pretransferrin zone, bands 14 and 15 in the transferrin zone, bands 16 and 17 in the posttransferrin zone, and band 4 in the prealbumin zone. The band 9 protein was definitely $\alpha$-livetins, since it migrated to the same position as the blood plasma band. Bands 10 and 11 may be regarded as $\beta$-livetins, as designated previously by Change et al. ${ }^{7)}$ and Dixson and CotTerill ${ }^{9)}$. Except for transferrin, the other yolk protein bands were not identified. Further studies are needed to clear the coagulating ability of egg yolk proteins which control gel textual properties.

\section{References}

1) Ogawa, N. and H. Tanabe (1989) Effect of Storage of Shell Eggs on Heat-induced Aggregation of Yolk and Whole Eggs, Sci. Cookery, 22 : 69-73.

2) Tanabe, H. and N. Ogawa (1980) Comparative Studies on Physical and Chemical Property of Avian Eggs. 5. Horizontal Polyacrylamide Gradient Gel Electrophoretograms of Chicken (Gallus domestics) Egg White Proteins, Japan Poult. Sci., $17: 242-248$.

3) Tanabe, H. and N. Ogawa (1980) Comparative Studies on Physical and Chemical Property of Avian Eggs. 4. Horizontal Polyacrylamide Gradient Gel Electrophoretograms of Chicken (Gallus domestics), Quail (Coturnix coturnix japonica), Golden Pheasant (Chysolophus pictus), Silver Pheasant (Gennaeus nycthemerus), Duck (Anas platyrhyncos domestica), Muscovy Duck (Cairina moschata) and Pigeon (Columba livia) Egg Yolk, Japan Poult. Sci., 17 : 109-115.

4) Tanabe, H., N. Ogawa, K. Watanabe and S. Ebisawa (1981) Comparative Studies on Physical and Chemical Property of Avian Egg. 9. Genetic Control of Plasma and Yolk Prealbumin-2 (Pa-2), Phosvitin, Polymorphism in the Chicken (Gallus domestics), Japan Poult. Sci., 18 : 229-233.

5) Gahne, B., R Juneja and J. Grolmus (1977) Horizontal Polyacrylamide Gel Electrophoresis for the Simultaneous Phenotyping of Transferrin, Post-transferrin, Albumin and Post-albumin in the Blood Plasma of Cattle, Anim. Blood Grps. biochem. Genet., 8 : 127-137.

6) Williams J. (1962) A comparison of Conalbumin and transferrin in the domestic fowl, Biochem. J. $83:$ 355-363.

7) Chang, P., W.D. Powrie and O. Fennema (1970) Disc Gel Electrophoresis of Proteins in Native and Heat-treated Albumin, Yolk and Centrifuged Whole Egg, J. Food Sci., 35 : 774-778.

8) Cotterill, O.J., J. Glauert and H.J. Bassett (1976) Emulsifying Properties of Salted Egg Yolk After Pasteurization and Storage, Poultry Sci., 55 : 544-548.

9) Dixon, D.K. and O.J. CotTerill (1981) Electrophoretic and Chromatographic Changes in Egg Yolk Proteins due to Heat, J. Food Sci., 46 : 981-990. 


\title{
加熱処理によるニワトリ卵黄蛋白質の泳動像の変化
}

\author{
小川宣子・田名部尚子
}

岐阜女子大学家政学部, 岐阜市 $501-25$

\begin{abstract}
新鮮卵黄蛋白質之貯蔵卵黄蛋白質の熱変性について水 平式ポリアクリルアミドグラジェントゲル電気泳動法を 用いて調べた。卵黄のみを分取し, $28^{\circ} \mathrm{C} て ゙ 6$ 週間保存 した試料を $80^{\circ} \mathrm{C}$ で 0〜 20 分加熱した。二ワトリ卵黄蛋 白質の泳動像は，6つの泳動域に分離された。その泳動 域は, (1) 1〜8のバンドをもつプレアルブミン域 (2) 9 のバンドをもつアルブミン域 (3) 10, 11 のバンドをも つポストアルブミン域 (4) 12,13 のバンドをあつプレ トランスフェリン域 (5) 14, 15 のバンドをむつトラン スフェリン域 (6) 16,17 のバンドをむつポストトラン スフェリン域であった。20 分の加熱まで泳動帯の存在 する耐熱性の高い蛋白質は, プレアルブミン域の 1,3 , 6, 7 のバンドと, ポストアルブミン域の 10 のバンドで
\end{abstract}

あった。5 分までの加熱で存在し，20 分の加熱で殆ど みられないか, なくなる中程度の耐熱性の蛋白質は, プ レアルブミン域の 2 のバンド, ポストアルブミン域の 11 のバンド, プレトランスフェリン域の 13 のバンドの 泳動帯であった。そして, あっとも熱に敏感な蛋白質は, プレアルブミン域の 4 のバンドと, アルブミン域の 9 の バンドと, プレトランスフェリン域の 14 と 15 のバンド, ポストトランスフェリン域の 16 と 17 のバンドであった。 貯蔵卵黄の場合は, アルブミン域の 9 の蛋白質は 80 ${ }^{\circ} \mathrm{C}$ で 20 分加熱してもまだ存在していた。又, トランス フェリンの 14 の蛋白質は, 10 秒の加熱で消失した。

（家禽会誌，26：333～339，1989） キーワード : 鶏卵, 卵黄, 眝蔵鵎卵, 熱安定性, 電気泳動 